\title{
EDITORIAL
}

\section{Reflecting on the importance of scientific anniversaries - the SS Arrow oil spill in Chedabucto Bay, NS, in 1970}

Scientific anniversaries are times of appreciation and reflection appreciation of the significance of a discovery, event or process, the persons or people involved, and reflection of its longer significance to human-kind. For example, last year (2019) was the $50^{\text {th }}$ anniversary of the Apollo landing on the moon on July $20^{\text {th }}, 1969$ (Berg 2019), the first time humans had exited the Earth to land on another planetary body; the $75^{\text {th }}$ anniversary of Erwin Schrodinger's prescient book "What is Life" (Schrödinger 1944), which stimulated several advancements in molecular biology and structural chemistry that led to the discovery of the structure and role of DNA; the $150^{\text {th }}$ anniversary of the Periodic Table of the Chemical Elements, a landmark achievement in chemistry by the Russian scientist Dmitri Mendeleev (Szuromi 2019); and the $500^{\text {th }}$ anniversary of Leonardo da Vinci's death in 1519 (Wikipedia), whose many outstanding contributions to the sciences and arts were celebrated worldwide. These anniversaries make us pause and reflect on advancements in science that are important stepping stones of progress in our scientific knowledge and practice.

Closer to home in Nova Scotia, NSIS recognized its $150^{\text {th }}$ anniversary in 2012 and the contribution of the Institute to scientific dialogue in Nova Scotia and the Maritimes. That year was also the $50^{\text {th }}$ anniversary of the publication of Silent Spring, by the American author and marine scientist Rachel Carson. This remarkable book galvanized recognition of the harm being done to ecosystems by persistent toxic chemicals and that led to the world-wide environmental movement. The environment is at the heart of this editorial, drawing attention to the anniversary in 2020 of an event in eastern Canada that helped shape an important aspect of marine environmental research in Canada and beyond.

Fifty years ago, on Feb. $4^{\text {th }}$, 1970, the Liberian tanker SS Arrow ran aground on Cerberus Rock in Chedabucto Bay, on the east coast of Nova Scotia (Gordon et al. 2014; pers. observ.). Carrying 14,700 tons (108,000 barrels) of Bunker C fuel oil, the broken ship released about two-thirds of its cargo into the bay, much of it ending up on the bay's northern rocky coastline. Some of it emulsified into the water 
column and was transported away in ocean currents or consumed by zooplankton. Remaining oil was recovered from the wreck at the time by an emergency response program called Operation Oil, and biological surveys were initiated (Operation Oil 1970). More recently, as a result of the appearance of oil slicks, an additional several thousand litres of oil have been removed from the sunken ship (CBC News, Oct $\left.27^{\text {th }}, 2015\right)$. However, despite the activities by Transport Canada and the Coast Guard, oil is still present in the sediments in some coastal locations (Yang et al. 2018, Lane, D., pers.comm.).

The legacy of this spill to Canadian marine science, and Canada's capacity to respond to such events, is enormous and worth noting. In the years following the accident, studies ranging from the development of chemical methods (e.g., dispersant use, bioremediation) to the marine ecotoxicology of petroleum hydrocarbons were initiated (Gordon et al. 2014). Research programs were established to assess the fate and effects of oil in cold temperate and northern waters (Gordon et al. 2014), especially oil-sediment-biotic interactions. The Bedford Institute of Oceanography (BIO) became a center for such research, continuing to this day. One of NSIS's previous Presidents, Dr. James Stewart, contributed to this research through studies of the microbial degradation of oil in cold waters (Mulkins-Phillips and Stewart 1974). Emergency response capabilities to ship-based spills were gradually improved through research by the Canadian federal government and the oil industry, especially through programs at BIO. These proved invaluable for later Maritime spills, such as the one from the Kurdistan in Cabot Strait in 1979. Due to concerns about hydrocarbon effects on fisheries, especially on the juvenile stages, new techniques for aquatic and marine ecotoxicology were developed (e.g., Blaise et al. 1988; Wells et al. 1998). To ameliorate the impact of spills, a major program to test the efficacy and toxicity of oil spill dispersants was established at BIO (Doe et al. 1978; Wells 1984), a program that continues to this day (King, T., and Lee, K, per.comm.). Dispersant use guidelines were drawn up for Canada (EC 1984), with input from local scientists. Above all, the Arrow spill led to increased general public awareness of the threats of spilled oil to coastal water and sediment quality, the fisheries and marine wildlife (e.g. seabirds), and the need for enhanced protection and response.

Fifty years later, work continues periodically at the site of the Arrow spill, improving our understanding of the persistence of oil 
constituents, such as PAHs (polycyclic aromatic hydrocarbons), in littoral and sub-littoral coastal sediments (e.g., Lee et al. 2003, Yang et al. 2018). The research emphasis at BIO on dispersant efficacy and bioremediation approaches for cold water environments is important as many studies have shown that components of spilled oil persist for decades in coastal environments, especially low energy shallow water ones. The field of marine environmental risk assessment has also benefited from the questions posed by such spill incidents. In particular, from what has been learned in Nova Scotia, there are implications for spill preparedness in Arctic waters, given current and future increases in ship traffic. In summary, the legacy of the Arrow spill event is huge and should be noted.

Many benefits emerge from noting anniversaries of scientific events or issues that have led to the application of new science. Reflecting on these anniversaries, knowing the history of local events, and making known the various key scientific discoveries is an important role for the NSIS. Too often we forget past events, their significance or the efforts of previous investigators. In general, "it is probably easier to look back and weigh the importance of a particular scientific achievement of the past than to predict how science will influence the future" (Adelman 2019). Recalling the legacy of the Arrow spill is important. Hopefully, it will ensure that the NSIS, amongst other organizations, will continue to commemorate such markers of our scientific progress.

To conclude, it would be remiss to overlook three other anniversaries. The year 2019 was the $100^{\text {th }}$ birthday of Dr. James Lovelock, the outstanding British scientist whose chemical expertise led to the detection of chlorofluorocarbons (CFCs) that still threaten the Earth's ozone layer, though banned decades ago. Further, his insights contributed to seeing planet Earth as a whole self-regulating system, the GAIA Principle. The NSIS acknowledges his remarkable life and achievements, an anniversary indeed, and offers its best wishes! 2019 was also the 150th anniversary of the seminal journal Nature, an historic milestone in scientific communication. Finally, closer to home, 2020 is the $50^{\text {th }}$ anniversary of the epic voyage (1969-70) of the oceanographic research vessel CSS Hudson, when she circumnavigated North and South America, making numerous marine discoveries enroute. Stay tuned for much more on this story as this year (2020) progresses! 
Acknowledgements The author is grateful for the comments by Michael Butler, Donald Gordon, Ken Lee and David Richardson during preparation of this article.

\section{REFERENCES}

Adelman, J. (2019). Five notable scientific anniversaries in 2019. The Irish Times, Jan. $10^{\text {th }}, 2019$.

Berg, J. (2019). Editorial. A child of Apollo. Science 365(6450):203. July $19^{\text {th }}$ Issue.

Blaise, C., Sergy, G., Wells, P.G., Bermingham, N. \& Van Coillie, R. (1988). Biological testing development, application and trends in Canadian environmental protection laboratories. Toxicity Assessment 3:385-406.

Doe, K.G. \& Wells, P.G. (1978). Acute aquatic toxicity and dispersing effectiveness of oil spill dispersants: results of a Canadian Oil Dispersant Testing Program (1973-1977). Pages 50-65 in Chemical Dispersants for the Control of Oil Spills. ASTM STP 659. L.T. McCarthy, G.P. Lindblom and H.F.Walters, Eds.). American Society for Testing and Materials, Philadelphia, PA.

Environment Canada. (1984). Guidelines on the use and acceptability of oil spill dispersants, $2^{\text {nd }}$ edition. Environmental Protection Service Report EPS 1 EP 84 1. Environment Canada, Ottawa, ON.

Gordon, D.C., Lee, K., Wells, P.G. \& Keizer, P.D. (2014). Ch. 44. The Impacts of oil and gas activities on the marine environment. Pages 361372 in Yoyage of Discovery. Fifty Years of Marine Research at Canada's Bedford Institute of Oceanography. Eds. Nettleship, D.N., D.C. Gordon, C.F.M. Lewis and M.P. Latremouille. Bedford Institute of Oceanography, Oceans Association, Dartmouth, NS.

Lee, K., Prince, R.C., Greer, G.W., Doe, K.G., Wilson, J.E.H., Cobanli, S.E., Wohlgeschaffen, G.D., Alroumi, D., King, T. \& Tremblay, G.H. (2003). Composition and toxicity of residual Bunker C fuel oil in intertidal sediments after 30 years. Spill Science and Technology Bulletin 8: 187-199.

Mulkins-Phillips, G.J. \& Stewart, J.E. (1974). Effects of environmental parameters on bacterial degradation of Bunker $\mathrm{C}$ oil, crude oil and hydrocarbons. Applied Microbiology 28:915-922.

Operation Oil. (1970). Report of the Task Force - Operation Oil to the Minister of Transport. Information Canada, Ottawa, ON.

Schrödinger, E. (1944). What is Life? Cambridge University Press, Cambridge, UK. 194 p.

Szuromi, P. (2019). Setting the Table. Science 363(6426):464-465.

Wells, P.G. (1984). The toxicity of oil spill dispersants to marine organisms - a current perspective. Pages 177-202 in Oil Spill Chemical Dispersants: Research, Experience and Recommendations. STP 840 (T.E.Allen, Ed.). American Society for Testing and Materials, Philadelphia, PA. 
Wells, P.G., Lee, K. \& Blaise, C. (eds.) (1998). Microscale testing in aquatic toxicology: advances, techniques and practice. CRC Press, Boca Raton, FL.

Wikipedia. (2019). Leonardo de Vinci. http://en/wikipedia.org/wikipedia/ leonardo

Yang, Z., Shah, K., LaForest, S., et al. (2018). A study of the 46-year-old Arrow oil spill: Persistence of oil residues and variability in oil contamination along Chedabucto Bay, Nova Scotia, Canada. Journal of Cleaner Production 198:1459-1473.

Peter G. Wells, Dalhousie University

Editor, PNSIS 
